\title{
DREAMING THE WELFARE-STATE: INDIAN WOMEN-STUDIES- MOVEMENT, NEOLIBERALISM AND FEMINIST FUTURE
}

\author{
Cheshta Arora:
}

(D) https: / / orcid.org / 0000-0003-2470-7783

\begin{abstract}
Through an account of the history of women-studies-movements in India, the paper aims to interrogate the 'temporality' of feminist response to the neoliberal reality. By juxtaposing two dominant narratives situated differently, the paper appeals for a reevaluation of contemporary feminist knowledges that bemoan the loss of 'welfare state' and collective political struggles. Through a critical account of women-studies-movements in India, and the inability of their dominant stories to respond to the current conundrums of responding to the 'neoliberal' subject, the paper argues that it is not just the neoliberal reality which is hegemonic and all too powerful, but also the feminist stories that constitute it.
\end{abstract}

Keywords: Neoliberalism, feminist movement, sexual difference, welfare state.

\section{Resumo}

Neste artigo, através de uma descrição da história dos estudos e movimentos das mulheres na Índia, pretende-se interrogar a «temporalidade» da resposta feminista à realidade neoliberal. Ao justapor duas narrativas dominantes situadas de forma diferente, apela-se a uma reavaliação dos conhecimentos feministas contemporâneos que lamentam a perda do «Estado-providência» e das lutas políticas coletivas. Através de uma descrição crítica dos estudos e movimentos das mulheres na Índia, e da incapacidade das suas histórias dominantes em responder aos atuais dilemas de dar resposta ao tema «neoliberal», argumenta-se que não é apenas a realidade neoliberal que é hegemónica e demasiado poderosa, mas também as histórias feministas que a constituem.

Palavras-chave: Neoliberalismo, movimento feminista, diferença sexual, Estado-providência.

\section{Resumen}

En este artigo, a través de un relato de la historia de los estudios y movimientos de mujeres en la India, se busca interrogar la «temporalidad» de la respuesta feminista a la realidad neoliberal. Al yuxtaponer dos narrativas dominantes situadas de manera diferente, se apela a la reevaluación de los conocimientos feministas contemporáneos que lamentan la pérdida del «Estado de bienestar» y las luchas políticas colectivas. A través de un relato crítico de los estudios y movimientos de mujeres en la India, y de la incapacidad de

Manipal Academy of Higher Education (MAHE), Manipal, Karnataka 576104, India; School of Social Sciences, National Institute of Advanced Studies (NIAS), Bengaluru, Karnataka 560012, India.

Postal address: Room No.9, National Institute of Advanced Studies, IISc Campus, Bengaluru, India -560012 .

Electronic address: cheshta@nias.res.in 
sus historias dominantes en responder a las incógnitas actuales de dar respuesta a la cuestión «neoliberal», se sostiene que no sólo la realidad neoliberal es hegemónica y demasiado poderosa, sino también las historias feministas que la constituyen.

Palabras-clave: Neoliberalismo, movimiento feminista, diferencia sexual, Estado de bienestar.

\section{Introduction}

We do not also seem to be overly vexed about the coordinates of our knowledge-making enterprises... Have we built knowledge adequate for contemporary and future feminisms?

(Sreekumar 2017, 63)

Sreekumar posed the above question to the women-studies-movement in India arguing that our dominant story-telling obliges «our knowledge projects to attach themselves to current temporalities and politics...on the here and now ${ }^{1} »$ where «women studies is inclined to conceive the 'political' in crucially delimited ways - as covering the ground of (i) reform, (ii) citizenship and (iii) development» (ibid.). The term 'women studies movements' is used in the existing literature (Jain 1999; Pappu 2002) to refer to the mobilization for introducing women studies as a discipline in higher education in the 1970s in India. Sreekumar uses it with hyphenation, as 'women-studies-movement' (henceforth, WSM) to refer to the conjoint formation of women studies and women's movement in India post-1970s and locates certain tendencies within the WSM's narrative of itself. Her focus is on two stories that are always invoked to mark the beginning of women's studies in India ${ }^{2}$. She describes the first story as «the long fertile $19^{\text {th }}$ century with its clamour over the 'women's question'»3 (47), and the second as the «tumultuous decade of

See Das (2012) for a more extensive critique of politics caught in the here and now.

While a focus on tendencies always comes at a cost of generalization, it also allows us to think about the current predicaments and possibilities. Thus, a certain account of India's WSM is offered here at the cost of generalization but with footnotes wherever necessary to guide the interested readers.

3 This period overlaps with the period of Social Reform Movement in India that spanned from 1850s to 1940s; it focused on 'uplifting' women to eradicate social issues such as widow immolation, child marriage and struggled under that shadow of colonialism (Gandhi and Shah 1992; Khullar 2005). This period is well researched by feminist historians in India interrogating the ways in which the woman's question was tied to complex play of modernity and tradition and how Indian women's emancipation became synonymous to the reformation of the 'social' for the new breed of 'educated natives'; and the complex agency of the Indian women during this period - see Chatterjee (1987), Mani (1989), Sangari and Vaid (1989), Tharu and Lalita (1991), Chakravarti (2013). This literature, however, is contested by scholars who mark out other voices and movements during this period that weaved starkly different relationships between «the 
the 1970s» ${ }^{4}$ (ibid.) which witnessed the publication of the Towards Equality report $(1975)^{5}$, the emergence of autonomous women's movements in India and the establishment of women-studies centres in universities and the institutes of higher education.

By mapping the granularities of feminist/women's movement in India post1970s and its entanglements with the mood, economy and politics of neoliberalism, the first part of this paper argues that WSM did not just respond to the structural crises that erupted during the 1970s (Calman 1989), but was structured by this crises, as is reflected in its self-narrative post-1990s; also, that it is its own particular affective story-telling which contributes to a production of 'neoliberalism' as an all-encompassing hegemonic phenomenon. Consequently, its despair and hopelessness in the face of neoliberalism should be seen in light of this perceived moment of origin. The second section engages with the debate between Fraser and Butler vis-à-vis recognition and redistribution and the notion of 'threatening feminism' that Rottenberg weaves as a counter to neoliberal reality to argue that the figure of a welfare state prefigures and haunts all these texts as a certain future to fight for despite its failures everywhere.

By locating a certain tendency in the self-narrative of WSM, the text distinguishes «between a hope that does not yet have an end in view... and a hope that is (as hook suggests) so oriented to a specified future that no genuine rupture with the present would occur» (Colebrook 2010, 323-324). A self-narrative of hope or loss oriented towards a specified future promised by the welfare state cannot face the challenge of neoliberalism. Dream of a welfare state continues a hope in a certain idea of 'development' in which the place of woman (as educated, empowered, and equally distributed along the status quo), of politics (negotiation, advocacy between the civil society and the government), of a good life (of dignified

social, the political and the religious... gender is inextricably interwoven with caste, community and religion, ... chart[ing] very different modes for woman's emergence - both as a social and as an epistemic category» (Sreekumar 2017, 54). See also Rege (2013) and Sreemukar (2017) for detailed references to mark these diverse voices.

This period is identified as the 'third' phase of women's movement in India that began post1970s. Calman (1960) identifies two tendencies within the contemporary women's movement in India: First, «the rights wing», which focusses on issues of rights and equality and is largely urban-based. It engages with the government to pass and administer laws related to family matters, education, employment, health and violence against women. The other wing of the movement, the «empowerment» wing, with both urban and rural components and financial help from national and international funders, focusses on issues such as livelihoods, literacy, alcoholism, environment, reservation for women in local governments. The diverse groups working within the «rights» wing of the movement are either affiliated to political parties, independent social service agents, or autonomous organizations. Urban, middle-class and educated women play a crucial role in both the wings, which makes the two complementary to each other. This report was commissioned by the Government of India (GOI) in 1974. Its exact implications on the WSM are discussed later in the text. 
work and consumption) is always already given and is also reiterated in the vision that 'neoliberalism' sells. Thus, a certain hope oriented towards a specified future in welfare state will always give way to a certain despair vis-à-vis neoliberalism. Instead, the text pushes the reader towards a certain hopelessness «directed towards the present» (yet nurturing a certain hope that doesn't yet have an end) in order to «map out some future that is at once other than the present and yet referenced to an unfulfilled actuality of the present» (Colebrook 2010, 332). Finally, a move towards sexual difference as 'pure difference' that can open up the ground work to reimagine feminist relationship with time, space, and scale is hinted at in the end.

\section{Two crises}

\section{0-1990}

Post-1990s, the network of women studies scholars showed an active interest in documenting WSM in India ${ }^{6}$ as it realized that liberalization had changed the «terms of political discourse» (Agnihotri and Mazumdar 1995). Two challenges were identified for the future of WSM in India: (i) rise of the Hindu right-wing in national electoral politics (ii) rise of the middle-class and the consequent hypervisiblization of middle-class women post-1990s (Tharu and Niranjana 1994; John 1998). Similar to the lament that appeared in the Anglo-centric feminist scholarship on neoliberalism (Hemmings 2005; Roy 2009), members of the WSM mourned the loss/death of autonomous women's movements in India that flourished in the 1970s and 1980s.

The loss was expressed through the following three fears - (i) institutionalization, professionalization and NGOisation (Roy 2011) of the women's movement (ii) hyper-visiblization of middle-class, upper caste women and their claim to feminist politics (iii) the growing rift between women studies and women's movement marking the influx of postmodern/poststructuralist theories. Three kinds of responses emerged from these fears. First, a generational response took stock of the history of women's movement in post-independence India, its thrust areas, and proposed strategies for the future where the legacies of 1970s and 1980s were to be remembered and taken forward. Second response, accepting defeat, bemoaned the loss of women's movement, and the third response took the form of self-blame (Roy 2015). The 'future' of feminist praxisin all three responses appeared

See Kumar (1989; 1993), Gandhi and Shah (1992), Mazumdar (1994; 2007), Agnihotri and Mazumdar (1995), John (1996; 2008; 2014a), Patel (1998), Jain (1999), Ray (1999), Bhagwat and Rege (2002), Sharma, Kasturi, and Sarkar (2002), Pappu (2002), Khullar (2003), Roy (2009; 2011; 2015), Sharma (2017). 
either circular, i.e., as that which that will recover or repeat the glories of the past, or bleak, i.e., imagination of which has been collectively stifled, muted or subdued by the crises.

The seeds of this predicament, however, can be traced back to that moment in the narrative when the events of the 1970s are perceived as originary of WSM in India. In 1975, the then Prime Minister Indira Gandhi ${ }^{7}$ declared a 21-month long emergency from 1975-1977, which led to a suspension of elections and all civil liberties in India. It also-saw the emergence of various social movements, including women's movement and the publication of the Towards Equality (1974) report which highlighted the failures of the postcolonial state and its promises but, simultaneously, introduced various policy measures, sustaining hope in the temporal promise of postcoloniality. The report, thus, ruptured as well as consolidated the contract of the postcolonial state with its citizenry.

Multiple aspects of the report need to be considered to understand its significance, to understand how it became 'constitutive' of the narrative of 'loss' in the 1990s. First, it highlighted the failures of the Indian state, its «systemic discrimination and structural constrains for women in the development process» (Sharma 2017, 80-81), and caused a "crisis of conscience» among the authors of the report who considered themselves to be «the first generation beneficiaries of the equality clauses of the Constitution» (Mazumdar 2007, 106). Second, the report, regarded as a point of origin of WSM in India (Sharma 2017), became a site to (re) perform the nationalist fervour and (re)inscribe the faith in the promises of the postcolonial state. It is rife with references to the Constitution and its guarantees with an emphasis on the role of women in 'nation-building' giving new lease to the Nehruvian state and its imagined economy of socialist development, with (poor) working women at the center of it (John 1996).

Thus, for WSM, the report became a site of both critique and participation in the working of the state, a double-edged sword, surprisingly untainted by the repressive arm of the state that sanctioned it for the UN's first world conference on women in Mexico (John 2014b). The crises of the legitimacy of the postcolonial state, and the 'crises of conscience' for the members of WSM affected by the findings of the report inspired the movement and its (middle-class) actors to participate and make concrete the 'dream' of the postcolonial nation to provide for its citizens and become the primary organ of governance. It allowed them to partake and struggle anew for the postcolonial state which was promised but never delivered. Contrary to the Anglo-centric accounts that bemoan the loss/failure of an already existing albeit failing 'welfare state' (Eisenstein 2017), the 'loss' in the narrative of Indian WSM is a loss of a 'dream' of a welfare state that never really

Indira Gandhi, the first and only female Indian Prime Minister, was in office from 24 January 1966 to 24 March 1977, and from 14 March 1980 until her assassination in 31 October 1984. She was the daughter of Jawaharlal Nehru, the first Prime Minister of independent India. 
materialized but was promised by the postcolonial condition. Vibrant with a hope in the temporal promise of postcoloniality, WSM took it upon itself to realize the promise that was already faltering by the 1970s. It is the shock of structural adjustments during the 1990s that jolted the WSM in India, dreaming the dreams of the postcolonial 'welfare' state into a neoliberal 'reality'.

\section{0s-present}

The scholarship in the last twenty decades that began with the narratives of loss (of a dream) is followed by sporadic responses to this loss that further entrenched the 'neoliberal reality'. Thus, against the despair of the members of women-studies-movement, Roy (2011) argues for a paradigm which understands NGOs outside of the binary logic that produces them either as «do-gooders» or «sell-outs» and situates NGOs in the context of their ambivalent origins, heterogeneous and hybrid ways of functioning. Drawing from an earlier critique of 'loss', 'despair', and 'anxiety' in women's movement, Roy (2009; 2012; 2015) argues that hyper-visiblization can also suggest that feminism in India was not just alive and well but had achieved a commonsensical status.

While Roy's (2015) response to the crises is to introduce NGO's as necessary research objects and political actors in the contemporary social movement that had privileged 'autonomous collectives' to be the norms of feminist movements, John (1998) offered a conceptual and methodological alternative to re-evaluate the contours of postcolonial feminist knowledges in the given crises. According to John (1998), the fundamental concept that needs re-evaluation to mitigate the crises is 'gender', where she argues that unlike in the 'west', the problem of gender in India is less about the binary logic of sex/gender which has been a concern for multiple authors in the west. In contrast, another pair is proposed - culture \& politics - and history as a point of departure. Finally, drawing from this reconceptualization, two kinds of inquiries are theorized to be adequate for women studies scholarship in India: 1) providing better picture of 'meanings' and 'social locations' and 2) by conducting a genealogical exercise of our conceptual resources, understanding how social, political cultural, historical sedimentations change the meaning of some concepts in different settings.

These two responses have come to dominate the women studies scholarship in India on entanglements of women, gender and liberalization and the rise of the figure of the 'new women' and its tryst with modernity, liberalization and globalization ${ }^{8}$. An instance of this can be gauged through the literature that studies

To make this argument I focus on recent literature that offers ethnographies of women situated at the center or at the margins of the new economy through the lens of available subjectivities and modes of resistance. There are other works that focus on the processes of neoliberalism and 
the entry of middle-class women in new service industries that have come to thrive on the Indian economic and cultural landscape post-1990s. Over the past two decades the subjectivities of these 'new (middle-class) women' have been defined as 'appropriate', 'respectable' (Radhakrishnan 2009), and 'balanced' (Gilbertson 2014). Post-2010, such theorizations trickle down to other groups, documenting the flexible strategies of women marked by their caste and class locations (Vijayakumar 2013; Twamley and Siddharth 2019) but still aspiring to be 'appropriate' and 'respectable'.

These works either implicitly repeat the feminist narrative of 'loss' since this new globalized middle-class (women) of the 1990s don't experience the 'crises of conscience' that was available to the middle-class (women) of the 1970s (Deshpande 1998). Or a second response, in its attempt to find a way out of the impasse mentioned above, rests on the binary of west/east wherein it argues that 'resistance' is to be understood differently from the western standards where Indian women become 'entrepreneurial activists' (Gupta 2016) indulge in 'patriarchal bargains' (Twamley and Siddharth 2019) or 'relational reflexivity' as opposed to 'reflexive modernity' (Belliappa 2013). The scholarship, implicitly, comes to follow the mandate laid out by John (1998), (i) they offer rich descriptions of 'meanings' and 'social locations' that women come to occupy and (ii) how these locations, their social and cultural histories allow different modes of resistance, and of Roy (2015), where new arrangements are not to be seen in terms of a 'lack' when compared to the past arrangements but are simply situated in the logic of the present.

The political and scholarly responses to the contemporary feminist impasses mapped above limit the scalar, spatial and temporal reaches of feministengagement. Temporally, they offer either a glorious past, or an ambivalent, hybrid present as only two points of references for feminist engagement/theorizations. Spatially, they legitimize their scholarly accounts of resistance and politics by reiterating power difference between west and east. And in terms of scale, they offer a choice between either the benevolent nation-state vs. the adventurous free-market. WSM in India, albeit critical of these processes, is divided along these lines. The scholarship, which takes 'women' as its research object performs a politics of difference, of postcoloniality, which consequently tends to celebrate different modes of resistance and positionalities. This scholarship concerns itself with producing the feminist knowledge of the postcolonial marginal and takes its visiblization as a political task. The second scholarship takes the contours of 'women's movement' as its research object whereby a concrete and coherent movement is first identified and

their relation to intensified violence against women (Bannerji 2016), consumerism and nationalism (Chaudhary 2017) and financial services (Kabeer 2005).

«Patriarchal bargains» was first theorized by Kandiyoti (1988) to theorize different forms of patriarchy, used by Twamley and Siddharth (2019) to make sense of bargaining subjectivities in the neoliberal context. 
fixed in some near past, and its 'loss' in the present is bemoaned or a plea is made to adjust to the ambivalent, hybrid present. These available spatial, scalar, and temporal choices as the only choices available, however, are never contested. The WSM in India refuses to be multi-sited (Sreekumar 2017).

\section{Master narratives and their critiques}

What would it mean for WSM to become multi-sited? A plea for contextspecific feminist articulations was made in the 1980s when faced with a postmodern reality, third-world feminist articulations and the death of a subject. Both 'neoliberalism' and 'postmodernism', overlapping on historical time, drew charges of de-politicization, paralysis, and end of collective social movements (Butler 1992; Zalewski 2004). To make sense of these responses, the defenders of postmodernism offered two responses: 1) an explicit theoretical/political program for 'postmodern feminism' taking into account the new complexities of neoliberalism and conscious of third-world, de-colonial realities, 2) A more radical 'mode of critique' that destabilizes all attempts at a coherent definition/mandates ensuing from the terrain of 'postmodern'. This response aggressively defended postmodern as a 'way of seeing', a mode of critique that begins with a premise of 'anti-foundationalism'.

Fraser and Nicholson's (1988) treatment of postmodern feminism best exemplifies the first response. To the challenge of postmodernism which leads to an interrogation of 'woman' as an empirically given subject of feminism, and 'patriarchy' as a holistic system, they offered a six-point theoretical programme for postmodern feminism. On the other hand, avoiding any direct definition/mandate of 'postmodern feminism', Butler (1992) begins with a more fundamental question, «what is postmodernism?» and excavates layer by layer how something becomes a term, capable of producing effects of loss, nihilism and impending doom.

The crisis of 'postmodernism' becomes a fertile ground for enunciation of two kinds of registers for feminist politics. While Fraser's reformulation is hinged on democracy and inclusion within political economy as a site of feminist struggle and intervention as she makes a demand for 'redistribution' in addition to recognition, postmodernism's challenge to the subject of feminism allows Butler to reformulate and introduce 'culture' as a site of legitimate subversion of the political economy as well as the 'states' of being (Butler and Spivak 2007).

However, the old dichotomy of 'materialism/culture' as base/superstructure comes to haunt these two formulations and renders them irreconcilable. Moreover, the two formulations come to repeat the same political impasses within feminist theory and politics which are posed and constituted by the neoliberal crises as is apparent in the continued debate between Fraser (Fraser 1997; Fraser and Honneth 2003) and Butler (1998; Butler and Spivak 2007). It appears that it was 'relatively' 
easier for feminist scholars to accept the 'death of a subject' than the 'death of a (promise of a) welfare-state' ${ }^{\prime 10}$.

There is no real consensus among scholars on the relationship between neoliberalism and postmodernism. In some narratives, neoliberalism is seen as a 'new master narrative' (Braidotti 2005) succeeding the end of postmodernism, while for others 'postmodern theory' is a handmaiden of neoliberal market economy (Mohanty 2013) legitimizing individual desires, less confrontational policy of gender mainstreaming over collective, feminist action (Baden and Goetz 1997; Bacchi and Eveline 2003; Fraser and Honneth 2003; McRobbie 2009; Kantola and Squires 2012; Wilson 2015; Eisenstein 2017; Newman 2017). Neoliberalism is marked by various characteristics but predominantly by certain historical amnesia, a forgetting, a regression, and lapses of memory, ignorance or a certain resurgence in popular media which comes with a neoliberal appropriation forsaking emancipatory goals of feminism (Rottenberg 2018). This appropriation is perceived as another ground (like postmodernism, previously) to introduce certain fissures in the feminist movement as it divides women into «aspirational and non-aspirational cohorts, with different roles and expectations for two groups» (Rottenberg 2018, X). Consequently 'neoliberalism' becomes a phenomenon against which a feminist theory has to strike back (Braidotti 2005), become «threatening... with 'precarity' as a unifying factor» (Rottenberg 2018, X) re-signifying neoliberal feminism into a more «vigorous and inclusive ideology» (ibid.)

Thus, a feminist response, attuned towards political economy, falls back to a certain belief in state institutions. For instance, after defining the necessity for a 'threatening feminism', the meaning of which is grounded in political movements such as Feminism for 99, Black Lives Matter, code pink, and the feminist anti-war movement, Rottenberg (2018) insists upon the necessity of institutions needed to complement the above cited political movements and thus, falls back to an already available, vertical, institutional imagination of a 'welfare state'. A political continuation between her call for a 'threatening feminism' and feminist investment in the institution of state is supported by a concluding rhetoric of 'capturing' state. Suddenly, an army of 'us' is formed, which is presumed to be a collective constituted independently of the discursive power of the state-market nexus and is capable of 'capturing' the institution of state. One finds a similar reaffirmation of 'welfare, Keynesian state' in Eisenstein's narrative of shift from 'hegemonic feminism' of (US) government to 'transnational business feminism'

10 Who sings the nation state, book developed out of a conversation between Butler and Spivak (2007), seeks to interrogate this entity called nation-states, and its constitutive 'states', such as nationalism, statelessness, sovereignty produced by it. In opposition, critical regionalism, global, and a notion of an 'abstract state' are hinted at. A certain notion of 'welfare state', as an abstract bureaucratic entity, cleansed of its nationalism, is merely imagined as an ally that brings their position closer to Fraser's defense of welfare state as necessary to demand redistribution. 
(2017). Her account stands on the presumed violence wrought on the 'third-world state' by the neoliberal adjustment programs that «coerced opening of national economies to an unlimited influx of foreign capital and manufacturing» (36). A certain victimization of 'third-world state institutions' then becomes necessary to illustrate the regression of the "progress of the 60 s and $70 \mathrm{~s}$ », to argue for a revitalization of a 'welfare state' everywhere tout court, obliterating the fact that a partial 'success', if at all, of these institutions is a historically specific reality mostly exclusive to 'developed' countries.

\section{Feminist futures}

Anglo-centric feminist responses to 'neoliberalism' are too caught up in the immediacy of social movements, politics and intervention which limit it to merely oscillate between recreating, rejuvenating the promise of the welfare state, autonomous feminist movements or accept the present of NGOs as ambiguous actors of the neoliberal market (Funk 2013; Roy 2015). What is needed to arrest this swing of the pendulum is a rearrangement, in our narratives, of the given order of space, scale and time by a different logic that presupposes equality rather than perceive it as an end to be achieved. Even though this order is disrupted regularly through different movements and everyday struggle, our narratives play an inconspicuous role in containing the disruption and the chaos of politics, and the eruption of political that occurs in these movements is sanitized by the narratives. Thus, in the narrative of WSM, a state-sponsored report becomes the 'watershed moment' (strengthening the vertical order - of state at the top, civil society [WSM as mediators] and the 'poor women' at the bottom); and, in Rottenberg's narrative, the diverse 'threatening feminism' is contained by a singular, temporal end of a strong welfare state to be captured by an army of us (even though after the capture the army of us will again be distributed along the vertical order of state, civil society and grassroots). Like feminist interventions to historiography where one studies the past against the grain, through the absence and silences that constitute it, the neoliberal moment offers us a chance to study our present narratives against the grain and the silences that constitute it.

This paper has been hinting at following three orientations vis-à-vis neoliberalism that have been available as critiques for past few decades but are reiterated here to usher in different feminist narratives and praxis. Hence, instead of bemoaning the loss of welfare state or launching feminist campaigns to lay claim to it, (i) the advent of neoliberalism makes visible the cracks in the very institution of 'welfare state' as an entity which by its very design is never sustainable for all, sustained and constituted as it is by certain states of violence, exclusion, statelessness, imperialism. Instead of accepting the market as the new reality (as inherent in Roy (2011) and other positions discussed previously), (ii) we should be 
interrogating the cracks in the previous feminist regime of representationism and an over-reliance on 'here and now', where a privileged few from the north, from the middle-class, from the west etc. take it upon themselves to represent and empower everyone else while continuing their faith (albeit critical) in narratives of progress, development and empowerment, every time giving new lease to the present order. Finally, (iii) it also makes visible the cracks in any reliance on development and progress (feminist or otherwise) which by its very design renders the vast majorities on the globe 'underdeveloped', doomed forever to play the game of catch-up, of empowerment.

It remains to be seen how/what kind of political, theoretical groundwork is needed to sustain such orientations as commonsensical part of our narratives. A move towards sexual difference as 'pure difference', as an infinitive 'to differ', and a certain hopelessness directed towards the present order, 'introducing another relation to time' (Colebrook 2004; 2010) allows the ground work necessary to rethink the coordinates for feminist movement - outside of already available (though contingent) scales such as local, state, nation, transnational. While 'sexual difference' requires work in terms of its convergence with race, class and other differences and the kind of questions that it dis/enables, 'sexual difference' as a concept has traversed multiple meanings, definitions and rhetoric. It began as a specific anatomical difference between already available, quantifiable men and women and developed to signify pure difference, as an ontological condition that suggests a necessity in life 'to differ' (Colebrook 2010). It is this ontological condition 'to differ' that at least allows us to pose the aforementioned questions vis-à-vis neoliberalism, gender and feminist politics, ushering a narrative outside of loss or acceptance, of the here and now, the universal and the particular.

\section{References}

Agnihotri, Indu, and Vina Mazumdar. 1995. «Changing Terms of Political Discourse: Women's Movement in India, 1970s-1990s». Economic and Political Weekly 30 (29): 1869-1878. JSTOR: https:/ / www.jstor.org/stable/ 4403023.

Bacchi, Carol, and Joan Eveline. 2003. «Mainstreaming and Neoliberalism: A Contested Relationship». Policy and Society 22 (2): 98-118. DOI: https:/doi.org/10.1016/S14494035(03)70021-6.

Baden, Sally, and Anne Marie Goetz. 1997. 'Who Needs [Sex] When You Can Have [Gender]?: Conflicting Discourses on Gender at Beijing'. Feminist Review 56 (1): 3-25. DOI: https:/ doi.org/10.1057 / fr.1997.13.

Bannerji, Himani. 2016. «Patriarchy in the Era of Neoliberalism: The Case of India». Social Scientist 44 (3/4): 3-27. JSTOR: https:/ / www.jstor.org/ stable/24890241.

Belliappa, J. 2013. Gender, Class and Reflexive Modernity in India. London: Palgrave Macmillan. DOI: https:/ / doi.org/10.1057/9781137319227.

Bhagwat, V., and Sharmila Rege. 2002. Our Story: Twenty Years of IAWS. Pune: Indian Association for Women's Studies. 
Braidotti, Rosi. 2005. «A Critical Cartography of Feminist Post-Postmodernism». Australian Feminist Studies 20 (47): 169-180. DOI: https: / doi.org/10.1080/ 08164640500090319.

Butler, Judith, and Gayatri Chakravorty Spivak. 2007. Who Sings the Nation-State? Language, Politics, Belonging. London: Seagull Books.

Butler, Judith. 1992. "Contingent Foundations: Feminism and the Question of 'Postmodernism'». In Feminists Theorize the Political, edited by Judith Butler and Joan W. Scott, 3-21. New York: Routledge.

Butler, Judith. 1998. «Judith Butler, Merely Cultural, NLR I/227, January-February 1998». New Left Review 1 (227). Available at https: / / newleftreview.org/ issues / I227 / articles / judith-butler-merely-cultural.

Calman, Leslie J. 1989. 'Women and Movement Politics in India'. Asian Survey 29 (10): 940-58. Doi: https: / / doi.org/10.2307/2644790.

Chakravarti, Uma. 2013. Rewriting History: The Life and Times of Pandita Ramabai. New Delhi: Zubaan.

Chatterjee, Partha. 1987. The Nationalist Resolution of the Women's Question. Calcutta: Centre for Studies in Social Sciences.

Colebrook, Claire. 2004. «Postmodernism Is a Humanism: Deleuze and Equivocity». Women: A Cultural Review 15 (3): 283-307. DOI: https: / doi.org/10.1080/0957404042000291427.

Colebrook, Claire. 2010. «Toxic Feminism: Hope and Hopelessness after Feminism». Journal for Cultural Research 14 (4): 323-335. DOI: https: / doi.org/10.1080/14797581003765291.

Das, Anirban. 2012. Toward a Politics of the (Im)Possible: The Body in Third World Feminisms. Cambridge: Cambridge University Press. DOI: https: / doi.org/10.7135/UPO978184 3313427

Deshpande, Satish. 1998. «After Culture: Renewed Agendas for the Political Economy of India». Cultural Dynamics 10 (2): 147-169. DOI: https:/ doi.org/10.1177/092137409 801000205

Eisenstein, Hester. 2017. «Hegemonic Feminism, Neoliberalism and Womenomics: «empowerment» Instead of Liberation?» New Formations 91 (91): 35-49. DOI: https:/ doi.org/ 10.3898/NEWF:91.02.2017.

Fraser, Nancy, and Axel Honneth. 2003. Redistribution or Recognition? A Political-Philosophical Exchange. London: Verso.

Fraser, Nancy, and Linda Nicholson. 1988. «Social Criticism without Philosophy: An Encounter between Feminism and Postmodernism». Theory, Culture E Society 5 (2-3): 373-394. DOI: https: / doi.org/10.1177/0263276488005002009

Fraser, Nancy. 1997. 'Heterosexism, Misrecognition, and Capitalism: A Response to Judith Butler'. Social Text, no. 52/53: 279. Doi: https: / / doi.org/10.2307/ 466745.

Funk, Nanette. 2013. «Contra Fraser on Feminism and Neoliberalism». Hypatia 28 (1): 179-196. DOI: https:/ doi.org/10.1111/j.1527-2001.2011.01259.x.

Gandhi, Nandita, and Nandita Shah. 1992. The Issues at Stake: Theory and Practice in the Contemporary Women's Movement in India. New Delhi: Kali for Women.

Gilbertson, Amanda. 2014. «A Fine Balance: Negotiating Fashion and Respectable Femininity in Middle-Class Hyderabad, India». Modern Asian Studies 48 (1): 120-158. DOI: https: / doi.org/10.1017/S0026749X1300019X.

Gupta, Hemangini. 2016. 'Taking Action: The Desiring Subjects of Neoliberal Feminism in India' 17 (1): 18.

Hemmings, Clare. 2005. «Telling Feminist Stories». Feminist Theory 6 (2): 115-139. DOI: https: / doi.org/10.1177 / 1464700105053690 
Jain, Devaki. 1999. "Women's Studies: A Crucial Key to Feminist Purpose". Paper presented at the University Grants Commission and IAWS Workshop on Women's Studies, Chandigarh, 15-17 April.

John, Mary E. 1996. «Gender and Development in India, 1970s-1990s Some Reflections on the Constitutive Role of Contexts». Economic and Political Weekly 31 (47): 3071-3077. JSTOR: www.jstor.org/stable/4404800.

John, Mary E. 1998. 'Feminism in India and the West: Recasting a Relationship'. Cultural Dynamics 10 (2): 197-209. https: / / doi.org/10.1177/092137409801000207.

John, Mary E. 2014a. «Feminist Vocabularies in Time and Space». Economic and Political Weekly 49 (22): 7-8. JSTOR: https: / / www.jstor.org/ stable/24479646.

John, Mary E. 2014b. 'The Emergency in India: Some Reflections on the Legibility of the Political'. Inter-Asia Cultural Studies 15 (4): 625-637. DOI: https: / doi.org/10.1080 / 1464 9373.2014.980558.

John, Mary E. ed. 2008. Women's Studies in India: A Reader. New Delhi: Penguin Books.

Kabeer, Naila. 2005. «Is Microfinance a 'Magic Bullet' for Women's Empowerment? Analysis of Findings from South Asia». Economic and Political Weekly 40 (44/45): 4709-4718. JSTOR: https: / / www.jstor.org/stable/4417357.

Kandiyoti, Deniz. 1988. «Bargaining with Patriarchy». Gender \& Society 2 (3): 274-290. DOI: https:/ doi.org/10.1177/089124388002003004.

Kantola, Johanna, and Judith Squires. 2012. «From State Feminism to Market Feminism?» International Political Science Review 33 (4): 382-400. DOI: https:/doi.org/10.1177/01 92512111432513.

Khullar, Mala, ed. 2005. Writing the Women's Movement: A Reader. New Delhi: Zubaan.

Kumar, Radha. 1989. «Contemporary Indian Feminism». Feminist Review 33 (1): 20-29. DOI: https:/ doi.org/10.1057/ fr.1989.28.

Kumar, Radha. 1993. The History of Doing: An Illustrated Account of Movements for Women's Rights and Feminism in India, 1800-1990. New Delhi: Kali for Women.

Mani, Lata. 1989. «Contentious Traditions: The Debate on Sati in Colonial India». In: Recasting Women: Essays in Colonial History, edited by Kumkum Sangari and Sudesh Vaid, 88-126. New Delhi: Kali for Women.

Mazumdar, Vina. 1994. «Women's Studies and the Women's Movement in India: An Overview». Women's Studies Quarterly 22 (3/4): 42-54.

Mazumdar, Vina. 2007. «Emerging State Feminism in India: A Conversation with Vina Mazumdar, Member Secretary to the First Committee on the Status of Women in India». International Feminist Journal of Politics 9 (1): 104-111. DOI: https://doi. org/10.1080/14616740601066465.

McRobbie, Angela. 2009. The Aftermath of Feminism: Gender, Culture and Social Change. Los Angeles: Sage.

Mohanty, Chandra Talpade. 2013. «Transnational Feminist Crossings: On Neoliberalism and Radical Critique». Signs: Journal of Women in Culture and Society 38 (4): 967-991. DOI: https:/ doi.org/10.1086/669576.

Newman, Janet. 2017. «The Politics of Expertise: Neoliberalism, Governance and the Practice of Politics». In Assembling Neoliberalism: Expertise, Practices, Subjects, edited by Vaughan Higgins and Wendy Larner, 87-105. Palgrave Macmillan. DOI: https:/ / doi. org/10.1057/978-1-137-58204-1_5.

Pappu, Rekha. 2002. «Constituting a Field: Women's Studies in Higher Education». Indian Journal of Gender Studies 9 (2): 221-234. DOI: https:/ doi.org/10.1177/0971521502009 00206. 
Patel, Ila. 1998. «The Contemporary Women's Movement and Women's Education in India». International Review ofEducation 44 (2/3):155-175.DOI:https: / doi.org/10.1023 / A:10031 25808644 .

Radhakrishnan, Smitha. 2009. «Professional Women, Good Families: Respectable Femininity and the Cultural Politics of a 'New' India». Qualitative Sociology 32 (2): 195-212. DOI: https: / doi.org/10.1007/s11133-009-9125-5.

Ray, Raka. 1999. Fields of Protest: Women's Movements in India.. Minneapolis, MN: University of Minnesota Press.

Rege, Sharmila. 2013. Writing Caste/Writing Gender: Narrating Dalit Women's Testimonies. New Delhi: Zubaan.

Rottenberg, Catherine. 2018. The Rise of Neoliberal Feminism. New York: Oxford University Press.

Roy, Srila. 2009. «Melancholic Politics and the Politics of Melancholia: The Indian Women's Movement». Feminist Theory 10 (3): 341-357. DOI: https:/ doi.org/10.1177/146470010 9343257.

Roy, Srila. 2011. «Politics, Passion and Professionalization in Contemporary Indian Feminism». Sociology 45 (4): 587-602. DOI: https: / doi.org/10.1177 / 0038038511406584.

Roy, Srila. 2015. «The Indian Women's Movement: Within and Beyond NGOization». Journal of South Asian Development 10 (1): 96-117. DOI: https:/doi.org/10.1177/0973174114 567368.

Roy, Srila. ed. 2012. New South Asian Feminisms: Paradoxes and Possibilities. New York: Zed Books.

Sangari, Kumkum, and Sudesh Vaid. eds. 1990. Recasting Women: Essays in Indian Colonial History. New Delhi: Kali for Women.

Sharma, Kumud, Leela Kasturi, and Lotika Sarkar, eds. 2002. Between Tradition, Counter Tradition and Heresy: Contributions in Honour of Vina Mazumdar. Delhi: Rainbow Publishers.

Sharma, Kumud. 2017. «Towards Equality: A Journey of Discovery and Engagement». Indian Journal of Gender Studies 24 (1): 80-97. DOI: https: / doi.org/10.1177 / 09715215166 78535 .

Sreekumar, Sharmila. 2017. «Equivocations of Gender: Feminist Storytelling and Women's Studies in the Contemporary». Indian Journal of Gender Studies 24 (1): 47-68. DOI: https: / doi.org/10.1177/0971521516678531.

Tharu, Susie, and K. Lalita, eds. 1991. Women Writing in India: Volume I: 600 B.C. to the Early 20th Century. New York: Feminist Press at The City University of New York.

Tharu, Susie, and Tejaswini Niranjana. 1994. «Problems for a Contemporary Theory of Gender». Social Scientist 22 (3/4): 93-117. DOI: https: / doi.org/10.2307/3517624.

Twamley, Katherine, and Juhi Sidharth. 2019. «Negotiating Respectability: Comparing the Experiences of Poor and Middle-Class Young Urban Women in India». Modern Asian Studies 53 (5): 1646-1674. DOI: https: / doi.org/10.1017/S0026749X17000816.

Vijayakumar, Gowri. 2013. «'I'll Be Like Water': Gender, Class, and Flexible Aspirations at the Edge of India's Knowledge Economy». Gender \& Society 27 (6): 777-798. DOI: https: / doi.org/10.1177/0891243213499445.

Wilson, Kalpana. 2015. «Towards a Radical Re-Appropriation: Gender, Development and Neoliberal Feminism: Debate: Gender, Development and Neoliberal Feminism». Development and Change 46 (4): 803-832. DOI: https:/ doi.org/10.1111/dech.12176.

Zalewski, Marysia. 2004. Feminism after Postmodernism: Theorising Through Practice. New York: Routledge. 
Cheshta Arora. PhD candidate at National Institute of Advanced Studies, Bengaluru, India. Her doctoral dissertation is an ethnographic study of women scientists, engineers and factory workers at three locations in India. The study is located at an intersection of feminist techno-science studies and labour studies. She is also interested in critical internet studies and urban studies.

Electronic address: cheshta@nias.res.in

Article received on the $30^{\text {th }}$ of June and accepted for publication on the $6^{\text {th }}$ of October 2020. 
